\title{
Toward an Empirical Analysis of Justice in Ecosystem Governance
}

\author{
Thomas Sikor ${ }^{1}$, Adrian Martin ${ }^{1}$, Janet Fisher ${ }^{2}$, \& Jun $\mathrm{He}^{1,3}$ \\ ${ }^{1}$ School of International Development, University of East Anglia, UK \\ ${ }^{2}$ School of Geosciences, University of Edinburgh, UK \\ ${ }^{3}$ College of Economics and Management, Yunnan Agricultural University, China
}

\author{
Keywords \\ Ecosystem services; governance; justice; \\ Payments for Ecosystem Services; Reducing \\ Emissions from Deforestation and Forest \\ Degradation (REDD+); equity.

\section{Correspondence} \\ Thomas Sikor, School of International \\ Development, University of East Anglia, \\ Norwich, NR4 7TJ, UK. \\ Tel: +44-1603-593372; fax. +44-1603-451-999. \\ E-mail: t.sikor@uea.ac.uk \\ Received \\ 6 March 2014 \\ Accepted \\ 20 August 2014 \\ Editor \\ Mark Lubell
}

doi: $10.1111 /$ conl.12142

\begin{abstract}
The 2010 Nagoya Protocol under the Convention on Biological Diversity and recent changes in the policies of major international conservation organizations highlight current interest in revisiting the moral case for conservation. Concerns with equity and human rights challenge well-established notions of justice centered on human responsibility toward nature, the common good or the rights of future generations. This review introduces an empirical approach to the analysis of justice and shows how conservation scientists can apply it to ecosystem services-based governance (or in short, ecosystem governance). It identifies dominant notions of justice and points out their compatibility with utilitarian theories of justice. It then discusses the limited appropriateness of these notions in many contexts in which conservation takes place in the Global South and explores how technical components of ecosystem governance influence the realization of the notions in practice. The review highlights the need for conservation scientists and managers to analyze the justice of ecosystem governance in addition to their effectiveness and efficiency. Justice offers a more encompassing perspective than equity for the empirical analysis of conservation governance.
\end{abstract}

\section{Introduction}

There are strong reasons to take a fresh look at justice in conservation now. Most fundamentally, conservation remains a deeply ethical undertaking, having concerns for the common good, nature and the prospects of future generations at its core. The significance of justice concerns and current interest in revisiting past justifications of conservation find illustration in the 2010 Nagoya Protocol on Access and Benefit Sharing under the Convention on Biological Diversity. In addition, virtually all major international conservation organizations have recently revised their mission statements or issued new policies to safeguard affected people's rights in an effort to recalibrate the balance between global and local interests (Martin et al. 2013a).

In addition, the spread of ecosystem services-based governance (henceforth, "ecosystem governance") brings about a readjustment of rights and responsibilities in conservation. This is because its analytical approach generates insights regarding the trade-offs between different kinds of ecosystem services and between various kinds of stakeholders, revealing that these are at the heart of ecosystem management (Ronnback et al. 2007; Daw et al. 2011). Ecosystem governance seeks to resolve the tradeoffs in a new manner in order to enable effective and lasting conservation. This applies to all forms of ecosystem governance, such as Payments for Ecosystem Services (PES), revenue-sharing mechanisms around protected areas, and Reducing Emissions from Deforestation and Forest Degradation (REDD+).

The resolution of trade-offs can be interrogated from a justice perspective (Luck et al. 2012; Chan \& Satterfield 2013). Justice is about what is morally right, being "the first virtue of social institutions" (Rawls 1971: p. 3). Ecosystem governance is amenable to justice analysis because it sets up relationships between stakeholders, such as between the providers and users of ecosystem 
services. Governance affects the distribution of benefits and duties among stakeholders and requires collective decisions about the objectives of conservation iand the methods to achieve these. This is important from a social perspective, as governance should be not only effective and efficient but also just (e.g., Bremer et al. 2014), and from an ecological perspective, because the environmental behavior of stakeholders is likely to depend on how they perceive the legitimacy and fairness of ecosystem governance (Pascual et al. 2010; Muradian et al. 2013).

We argue in this review that this fresh look at justice would benefit from what we call an empirical approach (cf. Schlosberg 2007; Walker 2011; Sikor 2013a). An empirical approach recognizes the plurality of justice in the sense that more often than not, stakeholders do not agree on a single definition of what is morally right (Martin et al. 2013b). Another key premise is that notions of justice are contextual and experiential, in the sense that they depend on the particular political and historical setting and by the kinds of resources and responsibilities to be shared (He \& Sikor, under review). Empirical approaches complement the normative approaches known from environmental ethics and distributive theories of justice (e.g., Rawls 1971). A key difference is that empirical justice analysis does not start from a particular theoretical position, such as Rawls' theory of justice as fairness, but instead starts from actual (empirical) claims about environmental justice and the notions of justice used to support these. It investigates how certain notions of justice find support in public discourse, how they may become dominant, and may lose support again (Fraser 2009).

We begin our review by introducing the empirical approach at greater length. We subsequently apply it to ecosystem governance, identifying dominant notions of justice, examining their appropriateness in the contexts where ecosystem governance takes place in the Global South, and pointing out how technical governance features influence their realization in practice. The review combines a novel theoretical argument for the relevance of justice analysis with purposefully selected examples from recent research on the social dynamics of ecosystem governance.

\section{An empirical approach to justice in ecosystem governance}

The application of empirical justice analysis to ecosystem governance involves two distinct but overlapping lines of enquiry (cf. Sikor 2013b). First, conservation scientists need to identify dominant notions of justice that accompany ecosystem governance, examine how appropriate these are in the contexts where conservation takes place, and analyze how these notions are operated in practice.

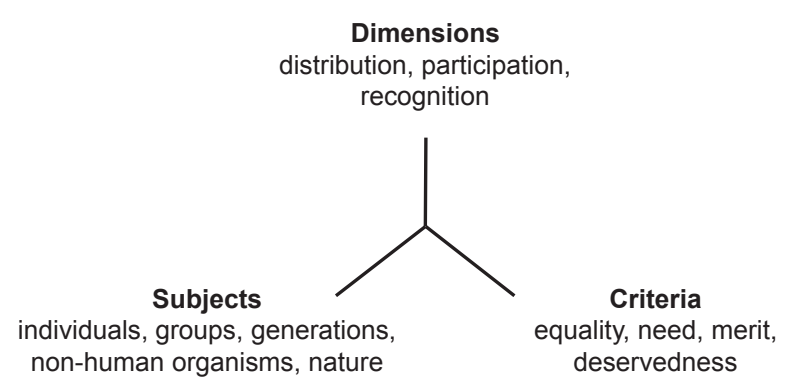

Figure 1 A simple conceptual framework for characterizing notions of justice.

Source: The authors, based on Sikor (2013a).

Establishing the interplay between notions, contexts, and actual practice is crucial because the moral implications of ecosystem governance become apparent only if we study actual practices of governance within particular contexts. The second line of enquiry is to characterize different stakeholders' notions of justice in particular contexts, explore their justification in public discourse, and determine how some of these notions find or lose support in public discourse. The study of justifications employed in public discourse helps to distinguish between mere statements of self-interest and notions of justice that are argued to possess wider relevance. The underlying premise is that in reality, there are often tensions between dominant notions of justice and those of local stakeholders, and that interactions between these ideas of justice are a major social dynamic influencing the nature and outcomes of ecosystem governance (Box 1).

An important element of the empirical approach is a simple conceptual framework to characterize notions of justice. We suggest three factors that help to understand stakeholders' notions: dimensions, subjects, and criteria (Figure 1; cf. Sikor 2013a):

(1) Dimensions refer to how notions emphasize concerns about distribution, participation or recognition (cf. Schlosberg 2007; Fraser 2009). Distribution is about the assignment of rights and responsibilities among stakeholders. Participation is often referred to as "procedural justice," directing attention to the roles of different stakeholders in decision making. Recognition is about acknowledging people's distinct identities and histories and eliminating forms of cultural domination of some groups over others.

(2) Subjects are the kinds of stakeholders considered to possess rights or bear responsibilities, have a role in decision making, deserve recognition, or are deserving of care from other stakeholders. Common examples in conservation are the local poor, entire local 
populations, indigenous peoples, global society, future generations, nonhuman organisms, and nature.

(3) Criteria are decision-making guidelines that organize the relationship between subjects for particular dimensions of justice. Typical criteria are equality, need, merit, and deservedness. For example, distribution of a natural resource among humans can be equal, needs based, or made to depend on merit.

Box 1: Justice and the ecological outcomes of PES in Rwanda.

Nyungwe National Park covers more than 900 $\mathrm{km}^{2}$ of lower montane forests and hosts a number of threatened and endemic species, including the owlfaced monkey. The forest has lost its apex grazers (buffalo and elephants) over the past few decades, and may have lost the leopard, its apex carnivore. The losses have been due to human pressure because the region is densely populated, living standards are low and natural resources remain a key source of livelihood. The Park is subject to various human uses, particularly hunting with snares, tree cutting, and mining.

A trial PES scheme provided financial incentives for local people from 2009 to 2012 to reduce human activity in the Park. Detailed community consultations helped to elicit local notions of justice and to incorporate them in the key features of the PES design. As a result, specific conservation indicators, performance targets and payment distribution varied from site to site. For example, one community chose to manage the majority of payments communally for the provision of public goods. In other sites, people felt it more just for most of the payments to be distributed equally among all households.

The PES trial led to significantly improved ecological outcomes compared to the rest of the park. However, similar improvements were also achieved in matched locations in which traditional park monitoring was increased. The main difference between the PES sites and these matched sites was significantly improved local attitudes toward the park. This change in attitudes might mean that the increase in ecological outcomes is more robust in the longer term in the PES sites compared to the matched sites. This suggests that PES schemes may not only enhance the moral case for conservation but also lead to more sustainable ecological outcomes if their design is compatible with local notions of justice.

Sources: Gross-Camp et al. (2012), Martin et al. (2014)
This simple conceptual framework helps to contrast and compare a wide range of justice notions, from deep green to those centered on individual human rights. For example, deep green positions (e.g., "justice to nature") tend to consider nature or nonhuman species as subjects of justice and accord them equal status to human beings (e.g., Naess 1990). Proponents of intergenerational justice juxtapose the current generation to future ones as subjects, often demanding an egalitarian distribution of rights and responsibilities between them (e.g., World Commission on Environment and Development 1987). Demands for universal human rights typically emphasize individual people are bearers of rights, combining the demand for equal procedural rights with a distribution that allows everyone to meet basic material needs (cf. Sen 2009).

Empirical justice analysis is different from existing empirical assessments of equity (e.g., Timko $\&$ Satterfield 2008; McDermott et al. 2013; Pascual et al., forthcoming). First, as indicated above, justice analysis is able to capture a wider range of ethical positions than equity assessments, such as concerns for ecological stewardship, the rights of nonhuman species and responsibilities to future generations-ethical concerns at the heart of conservation. Second, equity assessments typically center on local outcomes, such as the level of payments, their relative size in comparison with incurred costs, and distribution among resource managers (e.g., Muradian et al. 2010). In contrast, our approach attends to dynamics at local, national, and global scales by considering stakeholders beyond local resource managers. Third, justice analysis pays particular attention to the relationship between duty bearers and rights holders, such as between contemporary resource managers and future generations. This is often missing in assessments of local equity due to a more narrow preoccupation with local stakeholders and the distribution of benefits (e.g., García-Amado et al. 2011).

In the following, we show how conservation scientists might apply this empirical justice approach to ecosystem governance, organizing our discussion along the first line of enquiry introduced above. We begin by identifying dominant notions of justice associated with ecosystem governance and pointing out their compatibility with utilitarian theories of justice. We then examine their appropriateness in the contexts in which conservation takes place. In a third step, we investigate how aspects of the technical design of conservation affect how these dominant notions play out in practice.

\section{Dominant notions of justice in ecosystem governance}

Ecosystem governance in its theoretically ideal form tends to set up the relationships between involved stakeholders according to a distinct model (e.g., Ferraro 2001; 
Wunder 2005). The focus is on the providers and users of ecosystem services as well as the assignment of management duties and rewards to providers in relation to the benefits derived by users and contributions made by them. Key stakeholders are various kinds of people and social groups within a particular locality, country, or even worldwide. Providers and users are assumed to interact with each other on the basis of marginal utility, in which ecosystem services can be secured where at least one user values the service higher than at least one provider expects to receive. This is the ideal model in the sense of a guiding image, even though actual governance practices often depart significantly from the abstract model.

There are various PES projects and programs around the world that illustrate the basic tenets of this model despite variations in their specific designs (e.g., Engel et al. 2008; Wunder et al. 2008). For example, China's central government has provided large funds to pay for the protection of upper watersheds since 1999 (He \& Sikor, under review). The Sloping Land Conversion Program provides seedlings and payments to farmers in upper watersheds for growing trees on land that they previously used for cultivation. The stated rationale is that upstream farmers provide important services to downstream people, and that farmers should be compensated for the losses incurred in the switch from cultivation to tree plantations. Participation in the Program is voluntary in principle, allowing farmers to opt out if the compensation does not cover their costs. Another illustration of the ecosystem governance model are the global, national and local REDD+ initiatives, which are intended to address the trade-off between forest conservation and the provision of agricultural crops, timber, etc.

These examples demonstrate how our proposed conceptual framework helps to reveal the dominant notions of justice that are associated with ecosystem governance in its ideal form. First, it reveals the focal dimension to be distribution, in the form of the assignment of management duties, rewards, benefits, and contributions. Second, it shows the most important subjects of justice to be the users and providers of ecosystem services, i.e., contemporary individuals. Third, the critical criterion used for organizing the relationship between users and providers is one of merit defined as marginal utility. The overall management objective, the duties and rewards of providers, and the benefits and contributions of users are all defined on the basis of marginal utility.

These dominant notions are compatible with utilitarian theories of distributive justice as long as "they improve overall human well-being," as Chan \& Satterfield (2013) have pointed out. A central branch of utilitarianism considers social actions to be just if the generated welfare gains outweigh any connected losses (e.g., Mill
1998). Such actions are morally right even if they make some stakeholders worse off. Ecosystem governance in its ideal form meets this moral requirement because voluntary interactions between providers and users lead to the maximization of aggregate utility.

\section{Examining the appropriateness of justice notions in particular contexts}

The second element of an empirical justice analysis is to examine how utilitarian notions of distributive justice are appropriate to the contexts in which conservation takes place. Even if ecosystem governance holds theoretical potential to serve justice and may realize this potential in some contexts, it may still fail to do so in others. Evidence suggests that the appropriateness of utilitarian notions depends on certain preconditions that are often not present in the Global South.

Conservation in the Global South often takes place in settings of pronounced economic inequality. Where some people live at or below a level of sustainable subsistence it is hard to justify applying notions of justice that emphasize the aggregate good irrespective of distributional effects. In such situations, environmental governance guided by utilitarian theory may displace marginalized people from land and exclude them from key sources of subsistence and income (Adams et al. 2004). Even where environmental interventions afford a new source of income in compensation for incurred losses, local people may lose some of their ability to respond to future opportunities or shocks (Fisher 2013). Or, better-off local stakeholders within generally poor populations may take advantage of new sources of income and accumulate further advantages (Daw et al. 2011). Moreover, governance that generates benefits mostly to global or northern stakeholders may not meet utilitarian standards, even where it does not make anyone worse off in the South (Martin et al. 2013a). The reason is that increases in income in the North may not maximize global well-being due to differences in marginal utility between North and South: because an additional pound has a more significant effect on the well-being of the poor than that of affluent people, global well-being increases more if the pound is spent in the South (Hicks et al. 2009). Similarly, it has been observed that increases in inequality can diminish well-being even when everybody's income rises (Clark et al. 2008).

Similarly, unequal power relations challenge the appropriateness of utilitarian notions of justice where ecosystem governance departs from the pure market model by involving intermediaries such as governments and NGOs. Stakeholders are in different positions to 
influence decisions over what overall amount of ecosystem services provision is desirable, and what modalities apply to individual provision. In most settings, the democratic principle of "one person, one vote" does not apply even where local people are invited to participate in environmental decision making or take part in political affairs as citizens. For example, local elites have been found to dominate decisions over watershed governance in India (Vira et al. 2012) and afforestation projects in Mexico (Corbera et al. 2007). Similarly, local elites and international conservation organizations often determine the objectives and modalities of environmental governance in the South, failing to empower disadvantaged people or even marginalizing them further (Clements et al. 2010; Leggett \& Lovell 2012).

Another important limitation on the appropriateness of dominant justice notions is simply that the involved stakeholders may not share them. For some stakeholders distributive issues may be secondary to recognition, such as access to spiritual sites (Martin et al. 2013a; Sikor 2013c) and the preservation of cultural lifestyles, customary visions of desirable environmental management and traditional knowledge (Turner et al. 2008). Others may assert the significance of procedural justice by demanding their involvement in decision making, for example, through consultative processes (Gross-Camp et al. 2012). Similarly, stakeholders may define the subjects of justice differently, for example, by considering the rights of future generations or attributing independent ethical standing to nature (e.g., Litzinger 2004). Ecosystem governance divorces concerns about distributive among contemporary stakeholders from concerns about distribution to future generations, even though intra- and intergenerational matters have been viewed as closely associated since the Brundtland Report (World Commission 1987).

Stakeholders may also disagree with the dominant justice criterion of merit, or that merit is defined as marginal utility. They may invoke notions of justice built on the conviction that ecosystem governance has to contribute to overcoming entrenched economic, political, and cultural inequalities by emphasizing needs over merit. For example, their demands may reflect Rawls' (1971) principle that any inequalities in distribution should favor the least well-off, i.e., that ecosystem governance should help diminish the gap between poor and rich. Alternatively, they may give priority to ensuring that all people can achieve a minimum livelihood threshold along the lines of Sen's (2009) capabilities approach. Such "pro-poor" orientations are common to much ecosystem governance in practice. For example, China's Sloping Land Conversion Programme emphasizes poverty alleviation next to watershed protection as an overarching goal, a combination found in policy texts, expressed by local officials and supported by villagers (He \& Sikor, under review). Likewise, the Mexican and Ecuadorian governments consider equity concerns together with environmental objectives in the design and implementation of PES (Pattanayak et al. 2010; Bremer et al. 2014).

Thus, the appropriateness of dominant justice notions in ecosystem governance depends on certain preconditions, in particular the presence of a reasonably level playing field and general consent to the primacy of utilitarian theories of distributive justice. Such preconditions are often not present in the Global South. The limited appropriateness of utilitarian notions is reflected in the rising popularity of rights-based approaches to conservation (Greiber et al. 2009). Rights-based approaches in their ideal forms derive from other notions of justice that emphasize meeting a minimum threshold for affected people (Martin et al. 2013a).

\section{The influence of technical design features on the realization of justice notions}

The third element in our empirical justice analysis is to consider how technical design features of ecosystem governance influence how justice notions are realized in practice. Of particular interest here are the key parameters of ecosystem governance: (1) the identification of trade-offs and affected stakeholders, (2) measurement of ecosystem service flows and (3) definition of benefits made available to providers. They all have direct implications for justice as technical as they may appear at first sight (Sikor 2013c).

The identification of trade-offs and of affected stakeholders bears direct influence on the justice of ecosystem governance in its distributive, procedural and recognition dimensions (cf. Hirsch et al. 2010). Distributive effects arise from the kinds of ecosystem services considered in the trade-off. Certain services of importance to some stakeholders (e.g., agroforestry products) may get lost when the identification of the trade-off focuses on other services (e.g., carbon storage vs. land for cultivation; Lansing 2011). Effects on procedural justice arise from the decision making procedures employed to identify the trade-off and the desirable level of ecosystem services provision. The procedures can rely on scientific expertise, multistakeholder processes or other means, having different implications for the opportunity to participate of various stakeholders (Munda 2008; Garmendia \& Pascual 2013). Issues of recognition arise because stakeholders may hold different visions of the ecosystem, have different histories in their engagement with the ecosystem and apply different types of 
knowledge and practices to management (Hirsch et al. 2010; Forsyth \& Sikor 2013).

The measurement of ecosystem services flows also creates implications for justice. Measurement can have distributive implications since the employed methodologies tend to capture some changes in ecosystem services flows and fail to do so for others. Using REDD+ as an example, the measurement of carbon stocks by way of remote sensing yields a wide range of estimates depending on the remote imagery and processing technology employed (Qureshi et al. 2012). Changes in carbon stocks due to forest degradation are chronically difficult to measure by way of remote sensing technology, which means that some types of forest management employed by particular stakeholders are easier to capture than others (Mertz et al. 2012). Both measurement problems cause direct distributive effects because some protection of carbon stocks undertaken by some stakeholders are captured and eventually rewarded, whereas others are not (Sikor 2013c). In addition, measurement methodologies have different effects on participation and recognition. Participatory forest monitoring offers more opportunities for various kinds of stakeholders to participate in the generation of data and validate different forms of knowledge than expert-driven carbon monitoring (Danielsen et al. 2013; Sikor 2013c).

Similarly, the choice of benefits made available to providers creates justice effects because determining the kinds of transferred benefits involves questions of social value. Whose values come to matter raises issues of recognition, particularly where monetary payments are used in local systems of exchange that are not fully monetized (Muradian et al. 2010). Monetary payments may cause detrimental effects on the cultural values that local people attribute to forests, something that is often discussed as crowding out of intrinsic values (Vatn 2010; Narloch et al. 2012; García-Amado et al. 2013). Monetary transfers may even amount to bribery where local people face economic, political, and cultural discrimination and may not have much choice but to accept payments in return for foregoing demands of recognition of their own cultural values (Martin et al. 2013a). However, in other contexts, monetary payments may also serve to enhance the values stakeholders attach to ecosystems (Karky \& Skutsch 2010).

\section{Conclusions: ecosystem governance and justice}

Justice is an integral feature of ecosystem governance because governance almost always has moral implications, be it changes in the distribution of rights and responsibilities, people's participation in decision making or the recognition of their particular identities and histories. As a consequence, ecosystem governance typically incorporates elements designed to serve justice, such as voluntary interactions between users and providers of ecosystem services or compensation mechanisms. Yet, the justice-relevant elements go beyond those explicitly dedicated to bringing about justice or avoiding injustice. They extend to ostensibly technical design features since those may cause effects on distribution, participation, or recognition.

Thus, it is important for conservation scientists to analyze the justice of ecosystem governance in theory and practice, just like its effectiveness and efficiency. Empirical justice analysis offers a more encompassing perspective than existing equity assessments due to the consideration of a wider range of moral concerns, attention to dynamics at local, national and global scales, and reflection on the relationship between right holders and duty bearers.

Application of empirical justice analysis to ecosystem governance can produce new insights for conservation scientists. Perhaps most importantly, attention to justice indicates why stakeholders support ecosystem governance even though it requires them to forego certain resource uses. For example, rural Rwandans back the conservation of biodiversity even though they have to give up hunting, tree-cutting and mining (Box 1). Upland farmers in China champion the conversion of agricultural fields to tree plantations for watershed protection although trees yield lower incomes than agricultural crops (He Jun \& Sikor, under review). In addition, attention to stakeholders' notions of justice helps to illuminate the causes of conservation conflicts because conflicts are often due to competing ideas about what is just or unjust (Redpath et al. 2013). It helps to explain the frequent phenomenon that governments favor egalitarian distributions in PES (Pattanayak et al. 2010): governments may combine environmental with redistributive goals because utilitarian notions may find little support in public discourse. It also helps to understand why some participants in PES resist the implementation of ecosystem governance (Vira et al. 2012): they may not consider the underlying utilitarian ideas morally right. This applies to both users of ecosystem services who question the moral case for paying resource managers (Porras et al. 2008) as well as resource managers who emphasize the moral standing of rights to a minimum livelihood or selfdetermination (Ibarra et al. 2011).

These insights demonstrate how conservationists can benefit from practical applications of an empirical justice approach in the future. Conservationists may develop applied tools that help stakeholders to verbalize their 
notions of justice, acknowledge any differences and transform conflicts (e.g., Gritten et al. 2009). They may gain from applying operational procedures compatible with various notions of justice beyond the rights-based approaches of current interest (e.g., Greiber et al. 2009). Attention to justice may even open up a new platform for dialogue between proponents and critics of ecosystem governance, the latter including those who are concerned about the exclusion of local people (e.g., Brockington \& Igoe 2006) and others dedicated to meeting human obligations toward nonhuman species and nature (e.g., Doak et al. 2013). Once both proponents and critics realize their shared commitment to justice and make their attachments to particular notions of justice explicit, they may be better able to engage in a constructive dialogue. After all, they all believe in the power of justice as a motive for human action.

\section{Acknowledgments}

We thank Edward T Game and two anonymous reviewers for very helpful comments. This work results from the project 'Just Ecosystem Management' (NE/I003282/1) supported from the Ecosystem Services for Poverty Alleviation Programme (ESPA) and the I-REDD+ project funded by the European Union (Project No. 265286). The ESPA programme is funded by the Department for International Development (DFID), the Economic and Social Research Council (ESRC) and the Natural Environment Research Council (NERC).

\section{References}

Adams, W.M., Aveling, R., Brockington, D. et al. (2004). Biodiversity conservation and the eradication of poverty. Science, 306, 1146-1149.

Bremer, L.L., Farley, K.A. \& Lopez-Carr, D. (2014). What factors influence participation in payment for ecosystem services programs? An evaluation of Ecuador's SocioPáramo program. Land Use Policy, 2014, 122-133.

Brockington, D. \& Igoe, J. (2006). Eviction for conservation: a global overview. Conserv. Soc., 4, 424-470.

Chan, K.M.A. \& Satterfield, T. (2013). Justice, equity, and biodiversity. Pages $434-441$ in S.A. Levin, editor. The encyclopedia of biodiversity. Elsevier, Oxford.

Clark, A.E., Frijters, P. \& Shields, M.A. (2008). Relative income, happiness, and utility: an explanation for the Easterlin paradox and other puzzles. J. Econ. Lit., 46, 95-144.

Clements, T., John, A., Nielsen, K., An, D., Tan, S. \& Milner-Gulland, E.J. (2010). Payments for biodiversity conservation in the context of weak institutions:
Comparison of three programs from Cambodia. Ecol. Econ., 69, 1283-1291.

Corbera, E., Kosoy, N. \& Martinez, Tuna M. (2007). Equity implications of marketing ecosystem services in protected areas and rural communities: case studies from Meso-America. Global Environ. Chang., 17, 365380.

Danielsen, F., Adrian, T.P., Brofeld, S. et al. (2013). Community monitoring for REDD+: international promises and field realities. Ecol. Soc., 18, 41.

Daw, T., Brown, K., Rosendo, S. \& Pomeroy, R. (2011). Applying the ecosystem services concept to poverty alleviation: the need to disaggregate human well-being. Environ. Conserv., 38, 370-379.

Doak, D.F., Bakker, V.J., Goldstein, B.E. \& Hale, B. (2013). What is the future of conservation? Trends Ecol. Evol., 29, 77-81.

Engel, S., Pagiola, S. \& Wunder, S. (2008). Designing payments for environmental services in theory and practice: an overview of the issues. Ecol. Econ., 65, 663-675.

Ferraro, P.J. (2001). Global habitat protection: limitations of development interventions and a role for conservation performance payments. Cons. Biol., 15, 990-1000.

Fisher, J. (2013). Justice implications of conditionality in payments for ecosystem services: a case study from Uganda. Pages 21-45 in T. Sikor, editor. The justices and injustices of ecosystem services. Routledge, London.

Forsyth, T. \& Sikor, T. (2013). Forests, development, and the globalization of justice. Geogr. J., 179, 114-121.

Fraser, N. (2009). Scales of justice: reimagining political space in a globalizing world. Columbia University Press, New York.

García-Amado, L.R., Ruiz Perez, M. \& Barrasa García, S. (2013). Motivation for conservation: assessing integrated conservation and development projects and payments for environmental services in Le Sepultura Biosphere Reserve, Chiapas, Mexico. Ecol. Econ., 89, 92-100.

García-Amado, L.R., Ruiz Pérez, M., Reyes Escutia, F., Barrasa García, S. \& Contreras Mejía, E. (2011). Efficiency of payments for environmental services: equity and additionality in a case study from a Biosphere Reserve in Chiapas, Mexico. Ecol. Econ., 70, 2361-2368.

Garmendia, E. \& Pascual, U. (2013). A justice critique of environmental valuation for ecosystem governance. Pages 161-186 in T Sikor, The justices and injustices of ecosystem services. Earthscan, London.

Greiber, T., Janki, M., Orellana, M., Savaresi, A. \& Shelton, S. (2009). Conservation with justice: a rights-based approach. IUCN environmental policy and law paper No. 71. International Union for Conservation of Nature and Natural Resources, Gland.

Gritten, D., Saastamoinen, O. \& Sajama, S. (2009). Ethical analysis: a structured approach to facilitate the resolution of forest conflicts. Forest Policy Econ., 11, 555-560.

Gross-Camp, N., Martin, A., McGuire, S., Kebede, B. \& Munyarukaza, J. (2012) Payments for ecosystem services 
in an African protected area: exploring issues of legitimacy, fairness, equity and effectiveness. Oryx, 46, 24-33.

He, J. \& Sikor T. (under review). Notions of justice in payments for ecosystem services: insights from China's Sloping Land Conversion Program in Yunnan Province. Land Use Policy.

Hicks, C.C., McClanahan, T.R., Cinner, J.E. \& Hill, J.M. (2009). Trade-offs in values assigned to ecological goods and services associated with different coral reef management strategies. Ecol. Soc., 14, 1.

Hirsch, P.D., Adams, W.M., Brosius, J.P., Zia, A., Bariola, N. \& Dammert, J.L. (2010). Acknowledging conservation trade-offs and embracing complexity. Conserv. Biol., 25, 259-264.

Ibarra, J.T., Barreau, A., Del Campo, C., Camacho, C.I., Martin, G.J. \& McCandless, S.R. (2011). When formal and market-based conservation mechanisms disrupt food sovereignty: impacts of community conservation and payments for environmental services on an indigenous community of Oaxaca, Mexico. Int. For. Rev., 13, 318-337.

Karky, B.S. \& Skutsch, M. (2010). The cost of carbon abatement through community forest management in Nepal Himalaya. Ecol. Econ., 69, 666-672.

Lansing, D.M. (2011). Realizing carbon's value: discourse and calculation in the production of carbon forestry offsets in Costa Rica. Antipode, 43, 731-753.

Leggett, M. \& Lovell, H. (2012). Community perceptions of REDD+: a case study from Papua New Guinea. Clim. Policy, 12, 115-134.

Litzinger, R. (2004). The mobilization of "Nature": perspectives from North-west Yunnan. China Quart., 178, 488-504.

Luck, G.W., Chan, K.M.A., Eser, U., et al. (2012). Ethical consideration in on-ground applications of the ecosystem services concept. BioScience, 62, 1020-1029.

Martin A., Akol A. \& Phillips J. (2013a). Just conservation? On the fairness of sharing benefits. Pages 69-91 in T. Sikor, editor. the justices and injustices of ecosystem services. Earthscan, London.

Martin, A., McGuire, S. \& Sullivan, S. (2013b). Global environmental justice and biodiversity conservation. Geogr. J., 179, 122-131.

Martin, A., Gross-Camp, N., Kebede, B., McGuire, S. \& Munyarukaza, J. (2014). Whose environmental justice? Exploring local and global perspectives in a payments for ecosystem services scheme in Rwanda. Geoforum, doi:10.1016/j.geoforum.2013.02.006

McDermott, M.H., Mahanty, S. \& Schreckenberg, K. (2013). Examining equity: a multidimensional framework for assessing equity in payments for ecosystem services. Environ. Sci. Policy, 33, 416-427.

Mertz, O., Mueller, D., Sikor, T., et al. (2012). The forgotten D: challenges of addressing forest degradation in complex mosaic landscapes under REDD+. Geografisk Tidsskrift-Danish J. Geogr., 112, 63-76.
Mill, J.S. (1998). Utilitarianism. R. Crisp, editor. Oxford University Press, Oxford.

Munda, G. (2008). Social Multi-criteria evaluation for a sustainable economy. Springer, New York.

Muradian, R., Corbera, E., Pascual, U., Kosoy, N. \& May, P.H. (2010). Reconciling theory and practice: an alternative conceptual framework for understanding payments for environmental services. Ecol. Econ., 69, 1202-1208.

Muradian, R., Arsel, M., Pellegrini, L., Adaman, F., Aguilar, B. \& Many, A. (2013). Payments for ecosystem services and the fatal attraction of win-win solutions. Cons. Let., 6 , 274-279.

Naess, A. (1990). Ecology, community and lifestyle: outline of an ecosophy. Cambridge University Press, Cambridge.

Narloch, U., Pascual, U. \& Drucker, A. (2012). Collective action dynamics under external rewards: experimental insights from Andean farming communities. World Dev., 40, 2096-2107.

Pascual, U., Muradian, R., Rodriquez, L. \& Duraiappah, A. (2010). Exploring the links between equity and efficiency in payments for environmental services: a conceptual approach. Ecol. Econ., 69, 1237-1244.

Pascual, U., Phelps, J., Garmendia, E. et al. (forthcoming) Social equity matters in payments for ecosystem services. BioScience.

Pattanayak, S.K., Wunder, S. \& Ferraro, P.J. (2010). Show me the money: do payments supply environmental services in developing countries? Rev. Environ. Econ. Policy, 4, 254-274.

Porras, I.T., Grieg-Gran, M. \& Neves, N. (2008). All that glitters: a review of payments for watershed services in developing countries. International Institute for Environment and Development, London.

Qureshi, A., Pariva, Bodola R. \& Hussain, S.A. (2012). A review of protocols used for assessment of carbon stock in forested landscapes. Environ. Sci. Policy, 16, 81-89.

Rawls, J. (1971). A theory of justice. Harvard University Press, Cambridge.

Redpath, S.M., Young, J., Evely, A. et al. (2013). Understanding and managing conservation conflicts. Trends Ecol. Evol., 28, 100-109.

Ronnback, P., Crona, B. \& Ingwall, L. (2007). The return of ecosystem goods and services in replanted mangrove forests: perspectives from local communities in Kenya. Environ. Conserv., 34, 313-324.

Schlosberg, D. (2007). Defining environmental justice: theories, movements, and nature. Oxford University Press, New York.

Sen, A. (2009). The idea of justice. Penguin, London.

Sikor, T. (2013a). Introduction: linking ecosystem services with environmental justice. Pages $1-18$ in T. Sikor, editor. The justices and injustices of ecosystem services. Earthscan, London.

Sikor, T., editor. (2013b). The justices and injustices of ecosystem services. Earthscan, London. 
Sikor, T. (2013c). REDD+: justice effects of technical design. Pages 46-68 in Sikor, editor. The justices and injustices of ecosystem services. Earthscan, London.

Timko, J. \& Satterfield, T. (2008). Seeking social equity in national parks: experiments with evaluation in Canada and South Africa. Conservat. Soc., 6, 238-254.

Turner, N.J., Gregory, R., Brooks, C., Failing, L. \& Satterfield, T. (2008). From invisibility to transparency: identifying the implications. Ecol. Soc., 13, 2.

Vatn, A. (2010). An institutional analysis of payments for environmental services. Ecol. Econ., 69, 1245-1252.

Vira, B., Adams, W.M., Agarwal, C. et al. (2012). Negotiating trade-offs: choices about ecosystem services for poverty alleviation. Econo. Polit. Weekly, 47, 67-75.

Walker, G. (2011). Environmental justice: concepts, evidence and politics. Routledge, London.

World Commission on Environment and Development. (1987). Our common future. Oxford University Press, Oxford.

Wunder, S. (2005). Payments for environmental services: some nuts and bolts. Occasional paper No. 42. Center for International Forestry Research, Bogor.

Wunder, S., Engel, S. \& Pagiola, S. (2008). Taking stock: a comparative analysis of payments for environmental services programs in developed and developing countries. Ecol. Econ., 65, 834-852. 